\title{
DETERMINATION OF BIOACTIVE COMPOUNDS AND MINERAL SUBSTANCES IN LATVIAN BIRCH AND MAPLE SAPS
}

\author{
Māra Kūka, Ilze Čakste, and Endija Geršebeka \\ Faculty of Food Technology, Latvia University of Agriculture, Lielā iela 2, Jelgava, LV-3001, LATVIA \\ marakuka@apollo.lv
}

Communicated by Maija Dambrova

\begin{abstract}
Birch and maple saps contain carbohydrates and organic acids, B complex vitamins and vitamin $C$, tannins, flavonoids, glycosides and mineral substances. The aim of the study was to quantitatively determine the concentrations of bioactive compounds and mineral substances in Latvian birch (Betula pendula Roth.) and maple (Acer platanoides L.) saps. Electrical conductivity was determined (629 and $967 \mathrm{~S} / \mathrm{cm}$ in birch and maple saps, respectively) to characterise the total amount of mineral substances. In birch and maple saps the titratable acidity $(0.50$ and $0.70 \mathrm{mmol}$ of $\mathrm{NaOH}$ per litre of sap, respectively) and formol number $(0.25$ and $0.20 \mathrm{mmol} \mathrm{NaOH}$ per litre of sap, respectively) were determined. The protein concentration was found to be higher in maple sap (171 and $127 \mathrm{mg} / \mathrm{l}$, respectively). The antioxidant concentration, determined using quercetin as a standard, was $0.35 \mathrm{mg}$ of quercetin equivalents (QE)// in birch sap and $0.77 \mathrm{mg} Q \mathrm{QE} / \mathrm{l}$ in maple sap. In conclusion, Latvian maple sap contains more bioactive and mineral compounds than birch sap. Latvian birch sap contains up to $20 \%$ more glucose and fructose than birch sap produced in Finland, but Latvian maple sap contains 10 to $40 \%$ less sucrose than sap produced in North America.
\end{abstract}

Key words: birch sap, maple sap, bioactive compounds, mineral substances.

\section{INTRODUCTION}

Birch and maple saps are rich in carbohydrates, mineral salts, proteins, organic acids including aminoacids. These saps also contain $\mathrm{B}$ complex vitamins, vitamin $\mathrm{C}$, phenolic compounds, tannins, flavonoids and glucosides. Birch and maple saps are pleasant and freshening dietary drinks and both are used to produce syrup. Both saps are also known to possess some curative properties. Saps have been shown to be effective in the treatment of stomach ulcer, bronchitis, radicular pain, arthritis, removal of some potentially unwanted substances from the body and stimulation of overall metabolism (Drozdova et al., 1995; Deslauriers, 2000; Jiang, 2001; Sehm, 2007; Perkins and van den Berg, 2009). Extracts of maple sap and syrup have been shown to possess some antiproliferative effects on the colon cancer cells (González-Sarrías et al., 2012).

In most studies birch and maple saps produced from trees growing in Finland and North America, respectively, have been used to characterise chemical composition and properties of the respective sap. In Finland birch sap is used to produce syrup (Kallio et al., 1987; Kallio and Ahtonen, 1987b; Kallio, 1989; Kallio et al., 1987; 1989; 2006). Several studies have described the chemical composition of birch sap: concentration of organic acids (Kallio et al., 1985; Kallio and Ahtonen, 1987a), amino acids (Ahtonen and Kallio, 1989; Patzold and Bruckner, 2005), proteins
(Kallio et al., 1995; Jiang et al., 2001), carbohydrates (Kallio et al., 1985; Kallio and Ahtonen, 1987b), and micro- and macroelements (Harju and Hulden, 1990). Similarly, the chemical composition of maple sap has been described: concentration of mineral substances (Robinson et al., 1989), seasonal changes in amino acid concentration (Kozlowski and Pallardy, 1997), sucrose concentration varied from $0.5-10 \%$, and malic acid was observed to be the most common organic acid (Gaucher et al., 2003; Wong et al., 2003; Perkins and van den Berg, 2009). Various phenolic compounds have been found in maple sap and the concentration of these compounds could reach up to $0.1 \mathrm{mg} / \mathrm{l}$. Dominant compounds are sinapic and p-coumaric acids, and syringal and coniferal acids. In lesser amounts also vanillic, syringic, homovanillic and ferulic acids are present. Maple sap contains a number of flavonoids, like catechins, campherol and its glucosides, quercetine and its glucosides and others (Kermasha et al., 1995; Deslauriers, 2000; Abou-Zaid, 2008; Perkins and van den Berg, 2009). Some studies have tested the antioxidant, antiradical and antimutagenic activities of maple sap and syrup (Theriault et al., 2003; Legault et al., 2010).

Although Latvia is known as a producer and consumer of birch and maple saps, up to date no studies have characterised chemical composition and properties of sap obtained from trees growing in Latvia. Previously we have character- 
ised only the total content of phenolic compounds in birch and maple saps from Latvia. It was found that maple sap contains on average by $48 \%$ more total phenolic compounds than the birch sap (Kuka et al., 2010). The aim of the present study was quantitative determination of bioactive compounds and mineral substances in birch (Betula pendula Roth.) and maple (Acer platanoides L.) saps collected from trees grown in Latvia.

\section{MATERIALS AND METHODS}

Saps were obtained from birch (Betula pendula) and maple (Acer platanoides) trees growing in sandy soil away from roads near towns of Ozolpils $(56.685507 \mathrm{~N} 23.731600 \mathrm{E})$, Jelgava $(56.649137 \mathrm{~N} 23.651331 \mathrm{E})$ and Tukums $(56.8553437 \mathrm{~N} 23.0115635 \mathrm{E})$. Saps were collected in the early spring 2010 (end of March maple sap, beginning of April birch sap) during the most intense period of their production (first week of sap production).

Determination of titratable acidity and electrical conductivity. Titratable acidity was determined by potentiometric titration as described previously (Tanner, 1987). In brief, $25 \mathrm{ml}$ of sap was titrated with $0.25 \mathrm{M} \mathrm{NaOH}$ solution till $\mathrm{pH}$ 8.1, as measured using electrode SenTix 97T for potentiometric titration connected to a $\mathrm{pH}$-meter $\mathrm{pH} 538$ from WTW. Titratable acidity was calculated as $\mathrm{NaOH}$ $\mathrm{mmol} / \mathrm{l}$ of sap. Electrical conductivity was determined to characterise the total content of mineral substances using an electrode TetraCon 325 connected to a conductometer inoLab $\mathrm{pH} / \mathrm{Cond} 720$ from WTW.

Determination of content of mineral substances. Concentration of mineral substances was determined by microprocessor photometer MPM 3000 from WTW and commercially available reagent kits from MERCK according to manufacturer's protocol. The concentration of calcium ions was determined according to MERCK method $\mathrm{Nr}$. 1.14815.0001. The concentration of potassium ions was determined according to MERCK method Nr. 14562. The concentration of iron was determined according to MERCK method Nr.14761/2. The concentration of copper (II) ions was determined according to MERCK method Nr. 14767. The concentration of manganese ions was determined according to MERCK method Nr. 14770. The concentration of nickel ions was determined according to MERCK method Nr. 14785. The concentration of ammonium ions was determined according to MERCK method $\mathrm{Nr}$. 1.14752.0001 and the result was calculated as concentration of nitrogen in ammonia. The concentration of sulphate ions was determined according to MERCK method Nr. 1.14791.0001. The concentration of phosphate ions was determined according to MERCK method Nr. 1.14848.0001. The concentration of chloride ions was determined according to MERCK method Nr. 1.14897.0001. The concentration of nitrate ions was determined according to MERCK method Nr. 14556 and the result was calculated as concentration of nitrogen in nitrate ions. The concentration of nitrite ions was determined according to MERCK method $\mathrm{Nr}$.
N4/25 and the result was calculated as a concentration of nitrogen in nitrite ions.

Determination of formol number and protein amount. The formol number, which characterises the concentration of free amino acids, was determined as described previously (Tanner, 1987). In brief, to neutralise weak organic acids, $0.25 \mathrm{M} \mathrm{NaOH}$ solution was added to $25 \mathrm{ml}$ of sap till $\mathrm{pH}$ 8.1 , as determined by potentiometric titration. Then, formaldehyde solution (35\%) was added and the solution was titrated with $0.25 \mathrm{M} \mathrm{NaOH}$ solution till $\mathrm{pH} 8.1$ was reached. Results were calculated as the volume of $0.1 \mathrm{M} \mathrm{NaOH}$ in $\mathrm{ml}$ required to neutralise hydrogen ions liberated from $100 \mathrm{ml}$ of sample solution treated with water solution of formaldehyde.

The protein amount was determined by Lowry procedure (Lowry et al., 1951) using albumin as a standard. Results were calculated as $\mathrm{mg}$ of protein per litre of sap.

Determination of carbohydrate content by HPLC. Concentration of carbohydrates in sap was determined by high performance liquid chromatography (HPLC), (Shimadzu LC-20 prominence) as described previously (Kūka, 2008). In brief, calibration was made using standard solutions of fructose, glucose, sucrose and maltose at the following concentrations: $0.05 \mathrm{~g} / \mathrm{ml}, 0.01 \mathrm{~g} / \mathrm{ml}$ and $0.025 \mathrm{~g} / \mathrm{ml}$. Samples of sap $(10 \mu \mathrm{l})$ were injected into the chromatograph and analysed using $\mathrm{CH}_{3} \mathrm{CN}: \mathrm{H}_{2} \mathrm{O}$ (70:30 volume/volume, \%) as a mobile phase by flow rate $1.3 \mathrm{ml} / \mathrm{min}$.

Determination of ascorbic acid and antioxidant content. The ascorbic acid concentration was determined using iodometry. $50 \mathrm{ml}$ of sap were titrated with $0.01 \mathrm{M}$ iodine solution in the presence of starch as an indicator. The results were calculated as $\mathrm{mg}$ of ascorbic acid per litre of sap.

The antioxidant concentration was determined with 2,2-diphenyl-1-picrylhydrazyl $(0.02 \mathrm{mg} / \mathrm{ml})$ measuring absorbance at $517 \mathrm{~nm}$ using UV/VIS spectrophotometer Jenway UV 6405. Quercetin was used to produce the standard curve (concentrations $0.5-4.0 \mu \mathrm{g} / \mathrm{ml}$ ). The antioxidant content was expressed as quercetin equivalents (QE) - mg/l of sap (Theriault et al., 2006).

Data analysis. The results are presented as the mean \pm standard deviation. Data analysis was performed using in-built analysis of Microsoft Excel 2007.

\section{RESULTS}

Titratable acidity and electrical conductivity. Titratable acidity was determined using birch (Ozolpils) and maple sap (Ozolpils) samples obtained in the first week of sap production. Average titratable acidity in the maple sap samples was $40 \%$ higher than in the birch sap samples (Table 1). Electrical conductivity was determined in birch (Ozolpils, Jelgava) and maple sap (Ozolpils, Tukums) samples. The electrical conductivity in maple sap was higher than in birch 
VARIOUS PARAMETERS OF BIRCH (Betula pendula Roth.) AND MAPLE (Acer platanoides L.) SAPS

\begin{tabular}{c|c|c|c|c|c}
\hline Sap & $\begin{array}{c}\text { Titratable } \\
\text { acidity, } \\
\mathrm{NaOH} \\
\mathrm{mmol} / \mathrm{l}\end{array}$ & $\begin{array}{c}\text { Formol } \\
\text { number, } \\
0.1 \mathrm{M} \mathrm{NaOH} \\
\mathrm{ml} / 100 \mathrm{ml}\end{array}$ & $\begin{array}{c}\text { Protein, } \\
\mathrm{mg} / \mathrm{l}\end{array}$ & $\begin{array}{c}\text { Ascorbic } \\
\text { acid, } \\
\mathrm{mg} / \mathrm{l}\end{array}$ & $\begin{array}{c}\text { Antioxidant } \\
\text { content } \\
\text { QE, } \mathrm{mg} / \mathrm{l}\end{array}$ \\
\hline Birch & $0.50 \pm 0.01$ & $0.25 \pm 0.01$ & $127 \pm 2$ & $3.2 \pm 0.01$ & $0.35 \pm 0.03$ \\
Maple & $0.70 \pm 0.02$ & $0.20 \pm 0.01$ & $171 \pm 8$ & $8.8 \pm 0.03$ & $0.77 \pm 0.09$
\end{tabular}

Data are presented as mean $\pm \mathrm{SD}$.

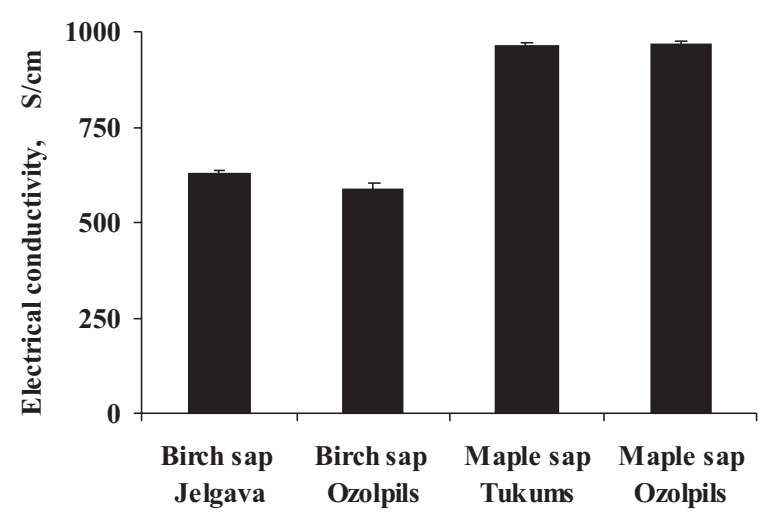

Fig.1. Electrical conductivity of birch (Betula pendula Roth.) and maple (Acer platanoides L.) saps. Data are presented as mean \pm SD.

sap on average by $58 \%$ (Fig. 1), indicating greater concentration of strong electrolytes in maple sap samples.

Content of mineral substances. The predominant macroelements in the birch and maple saps were found to be $\mathrm{Ca}^{2+}$ and $\mathrm{K}^{+}$ions and the prevailing trace elements were $\mathrm{Mn}^{2+}$ ions, while the dominant anions were sulphate ions (Table 2). Nitrate and nitrite concentrations in both birch and maple sap samples were negligible.

Formol number and protein amount. The formol number, which characterizes the concentration of free amino acids, was determined in birch (Ozolpils) and maple sap (Ozolpils) samples. The concentration of free amino acids was similar and negligible in both birch and maple sap samples (Table 1). The concentration of proteins was by $34.6 \%$ higher in maple sap than in birch sap (Table 1).

Carbohydrate content. Carbohydrate concentration was determined using HPLC in birch (Ozolpils) and maple sap (Ozolpils) samples. The monosaccharides glucose and fructose and disaccharide sucrose were identified in sap samples. The concentration of sucrose in the maple sap was 31-fold higher than in birch sap, while the concentration of fructose and glucose was 10-fold and 3-fold higher, respectively, in birch sap than in maple sap (Table 3). Other carbohydrates were below the identification threshold.

Content of ascorbic acid and total content of antioxidants. Concentration of ascorbic acid was determined using birch (Ozolpils) and maple sap (Ozolpils) samples. Concen-
CONCENTRATION OF MINERAL SUBSTANCES IN BIRCH (Betula pendula Roth.) AND MAPLE (Acer platanoides L.) SAPS

\begin{tabular}{l|ccccc}
\hline \multirow{2}{*}{$\begin{array}{c}\text { Mineral } \\
\text { substances }\end{array}$} & \multicolumn{2}{|c|}{ Birch sap, mg/l } & \multicolumn{2}{c}{ Maple sap, mg/l } \\
\cline { 2 - 5 } & Jelgava & Ozolpils & Tukums & Ozolpils \\
\hline $\mathrm{Ca}^{2+}$ & $53.3 \pm 0.1$ & $41 \pm 1$ & $61 \pm 1$ & $91 \pm 1$ \\
$\mathrm{~K}^{+}$ & $41.1 \pm 0.5$ & $66.4 \pm 0.1$ & $70.1 \pm 0.2$ & $78.9 \pm 0.1$ \\
$\mathrm{Mn}^{2+}$ & 0.5 & $0.520 \pm 0.006$ & - & $0.24 \pm 0.01$ \\
$\mathrm{Ni}^{2+}$ & - & $0.03 \pm 0$ & $0.15 \pm 0.02$ & $0.13 \pm 0$ \\
$\mathrm{Cu}^{2+}$ & 0.04 & - & - & - \\
$\mathrm{Fe}^{3+}$ & 0.10 & - & - & - \\
$\mathrm{NH}_{4}{ }^{+}-\mathrm{N}$ & $0.050 \pm 0.001$ & - & $0.080 \pm 0.001$ & - \\
$\mathrm{SO}_{4}{ }^{2-}$ & $36.10 \pm 0.06$ & $34.0 \pm 0.1$ & $39 \pm 1$ & $62.6 \pm 0.5$ \\
$\mathrm{PO}_{4}{ }^{3-}-\mathrm{P}$ & $2.06 \pm 0.01$ & $2.36 \pm 0.02$ & $4.13 \pm 0.09$ & - \\
$\mathrm{Cl}^{-}$ & - & $9.0 \pm 0.1$ & $9.0 \pm 0.1$ & $12.0 \pm 0.1$ \\
$\mathrm{NO}_{3}{ }^{-}-\mathrm{N}$ & $3.40 \pm 0.01$ & $3.40 \pm 0.01$ & $3.40 \pm 0.01$ & $3.40 \pm 0.01$ \\
$\mathrm{NO}_{2}{ }^{-}-\mathrm{N}$ & $0.008 \pm 0$ & $0.012 \pm 0$ & - & $0.115 \pm 0$ \\
\hline
\end{tabular}

Data are presented as mean $\pm \mathrm{SD}$.

Table 3

CONCENTRATION OF CARBOHYDRATES IN BIRCH (Betula pendula Roth.) AND MAPLE (Acer platanoides L.) SAPS

\begin{tabular}{l|c|c|c}
\hline \multicolumn{1}{c|}{ Sap } & Fructose, $\mathrm{g} / \mathrm{l}$ & Glucose, $\mathrm{g} / \mathrm{l}$ & Sucrose, $\mathrm{g} / \mathrm{l}$ \\
\hline Birch & $5.39 \pm 0.05$ & $4.46 \pm 0.04$ & $0.58 \pm 0.01$ \\
Maple & $0.55 \pm 0.01$ & $1.33 \pm 0.03$ & $17.95 \pm 0.05$
\end{tabular}

Data are presented as mean $\pm \mathrm{SD}$.

tration of ascorbic acid in maple sap was by $56 \%$ higher than in birch sap (Table 1).

Total concentration of antioxidants was characterised using quercetin equivalents and the obtained results show that maple sap samples contained around two times higher concentration of compounds with antioxidant properties than in birch sap samples (Table 1).

\section{DISCUSSION}

The present study quantitatively determined the concentration of bioactive compounds and mineral substances in saps obtained from birch (Betula pendula) and maple (Acer platanoides) trees growing in Latvia. The obtained results indicate that Latvian maple sap contains significantly more bioactive and mineral compounds than birch sap. The concentration of mineral substances in sap obtained from birch (Betula pendula) trees reflects the chemical composition of the soil where trees grow (Harju and Hulden, 1990). In addition, our results indicate that a similar tendency can be observed in sap obtained from maple (Acer platanoides) trees (Table 2). Overall, the concentration of mineral substances was higher in maple than in the birch sap (Table 2). These findings were in compliance with the results of electrical conductivity measurements (Fig. 1), which showed that maple sap contains higher concentrations of strong electrolytes 
and thus the concentration of mineral substances must be higher. It should be noted that the concentration of mineral substances much varies in maple sap and increases during the period of sap production (Robinson et al., 1989; Perkins and van den Berg, 2009). Dominant mineral substances are calcium and potassium. Maple sap is also rich in magnesium and manganese, while only small amounts of zinc, copper, iron, sodium and aluminium can be found. Birch sap mainly contains salts of potassium, calcium, magnesium, manganese and zinc (Harju and Hulden, 1990).

Although the overall concentration of bioactive compounds was higher in maple sap, the concentrations of free amino acids were similar and both birch and maple saps contained very low concentration of free amino acids (Table 1). This could be explained by the use of the first-week saps for the study. It has been shown that the concentration of free amino acids increases during the birch sap production period (up to $100-500 \mathrm{mg} / \mathrm{l}$ ) and that the most prevalent amino acids are glutamine, citrulline and glutamic acid (Ahtonen and Kallio, 1989; Jiang et al., 2001). In both birch and maple saps, the concentration of proteins increases in the last stage of the season (Kallio et al., 1995; Kozlowski and Pallardy, 1997; Jiang et al., 2001). Similarly, the total content of all organic acids found in the saps increases during the production period and the predominant acid in both birch and maple saps is malic acid (Kallio et al., 1985; Kallio and Ahtonen, 1987a; Perkins and van den Berg, 2009). Glucose, fructose and sucrose were the only carbohydrates identified in the sap samples (Table 3). Although birch and maple saps contain other carbohydrates, their content is negligible and they were not quantified. It has been shown that carbohydrate content does not depend on species or variety of the tree and the amount of carbohydrates in birch sap decreases in the following order: glucose, fructose, sucrose and galactose (Kallio and Ahtonen, 1987b). Sucrose is the dominant carbohydrate in the maple sap, while other carbohydrates like glucose and fructose are in small quantities, but the concentrations of stachyose, raffinose and xylose are negligible (Wong et al., 2003; Perkins and van den Berg, 2009). Latvian birch sap contains up to $20 \%$ more glucose and fructose (Table 3) than birch sap produced in Finland (Kallio and Ahtonen, 1987b), but Latvian maple sap contains up to 10 to $40 \%$ less sucrose (Table 3) than sap produced in North America (Kozlowski and Pallardy, 1997).

In conclusion, our results demonstrate that the overall content of Latvian maple (Acer platanoides) sap is richer in bioactive substances and mineral salts as compared to birch (Betula pendula) sap. The dominant carbohydrates in birch sap are glucose and fructose, while the sucrose is predominant in maple sap.

\section{ACKNOWLEDGMENTS}

The authors would like to thank Dr. pharm. Jānis Küka for his help in preparing this manuscript.

\section{REFERENCES}

Abou-Zaid, M. M., Nozzolillo, C., Tonon, A., Coppens, M., Lombardo, A. (2008). High-performance liquid chromatography and identification of aantioxidant polyphenols in maple syrup. Pharm. Biol., 46 (1-2), 117-125.

Ahtonen, S., Kallio, H. (1989). Identification and seasonal variations of amino acids in birch sap used for syrup production. Food Chem., 33 (2), $125-132$.

Deslauriers, I. (2000). Recovery, Separation and Characterization of Phenolic Compounds and Flavonoids from Maple Products. Montreal, Quebec: McGill University. 104 pp.

Drozdova, G., Demurov, E., Bakhilov, V., Frolov, V. (1995). Some aspects of pharmacological activity of birch sap and birch drag-preparations. In: Terazawa, M. (Ed.). Tree Sap (pp. 85-89). Sapporo: Hokkaido University Press.

Gaucher, C., Gougeon, S., Mauffette, Y, Messier, C. (2003). Seasonal variation in biomass and carbohydrate partitioning of understory sugar maple (Acer saccharum) and yellow birch (Betula alleghaniensis) seedlings. Tree Physiol., 25, 93-100.

González-Sarrías, A., Li, L., Seeram, N.P. (2012). Effects of maple (Acer) plant part extracts on proliferation, apoptosis and cell cycle arrest of human tumorigenic and non-tumorigenic colon cells. Phytother. Res., 26 (7), 995-1002.

Harju, L., Hulden, S. G. (1990). Birch sap as a tool for biogeochemical prospecting: [about micro and macro elements]. J. Geochem. Explor., 37 (3), $351-365$.

Jiang, H., Sakamato, Y., Tamai, Y., Terazawa, M. (2001). Proteins in the exudation sap from birch trees, Betula platyphylla Sukatchev var. japonica Hara and Betula verrucosa Her. Eurasian J. For. Res., 2, 59-64.

Kallio, H. (1989). Aroma of birch syrup. J. Agric. Food Chem., 37, 1367-1371.

Kallio, H., Ahtonen, S. (1987a) Seasonal variations of the acids in birch sap: [acids in birch sap]. Food Chem., 25 (4), 285-292.

Kallio, H., Ahtonen, S. (1987b). Seasonal variations of the sugars in birch sap: [sugars in birch sap]. Food Chem., 25 (4), 293-304.

Kallio, H., Lahenoja, M., Penttin, R. (1995). Electrophoretic profiles of birch sap proteins of Betula pubescens, $B$. pendula and $B$. pendula forma Carelica in Finland with reference to overall composition of sap. In: Terazawa, M. (Ed.). Tree Sap (pp.13-21). Sapporo: Hokkaido University Press.

Kallio, H., Ahtonen, S., Raulo, J., Linko, R.R. (1985). Identification of the sugars and acids in birch sap: [about acids and sugars]. J. Food Sci., 50 (1), 266-269.

Kallio, H., Karppinen, T., Holmbom, B. (2006). Concentration of birch sap by reverse osmosis. J. Food Sci., 50 (5), 1330-1332.

Kallio, H., Rine, S., Pangborn, R.-M., Jennings, W. (1987). Effect of heating on the headspace volatiles of Finnish birch syrup. Food Chem., 24 (4), 287-299.

Kallio H., Teerinen T., Ahtonen, S., Suihko, M., Linko, R. R. (1989). Composition and properties of birch syrup (Betula pubescens). J. Agric. Food Chem., 37, 51-54.

Kermasha, S., Goetghebeur, M., Dumont, J. (1995). Determination of phenolic compound profiles in maple products by high-performance liquid chromatography. J. Agric. Food Chem., 43 (3), 708-716.

Kozlowski, T. T, Pallardy, S. G. (1997). Nitrogen metabolism. In: Physiology of Woody Plants (pp. 189-209). New York: Academic Press.

Kuka, M., Cakste, I., Dimins, F., Gersebeka, E. (2010). Determination of phenolic compounds in birch and maple saps. In: Foodinnova 2010, International Conference on Food Innovation, 25-29 October 2010. (108 p.) Valencia.

Kūka, P. (2008). Pārtikas produktu analī̌̌u fizikāli k̦īmiskās metodes [Physical-Chemical Methods of Food Products Analysis]. Jelgava: LLU, 174 lpp. 
Legault, J., Girard-Lalancette, K., Grenon, C., Dussault, C., Pichette, A. (2010). Antioxidant activity, inhibition of nitric oxide overproduction, and in vitro antiproliferative effect of maple sap and syrup from Acer saccharum. J. Med. Food, 13 (2), 460-468.

Lowry, O. H., Rosebrough, N. J., Farr, A. L., Randall, R. J. (1951). Protein measurement with the Folin phenol reagent. J. Biol. Chem., 193 (1), $265-275$.

Patzold, R., Bruckner, H. (2005). Mass spectometric detection and formation of D-amino acids in processed plant saps, syrups, and fruit juice concentrates. J. Agric. Food Chem., 53, 9722-9729.

Perkins, T. D., van den Berg, A. K. (2009). Maple syrup - production, composition, chemistry, and sensory characteristics. In: Taylor, S. (Ed.). Advances in Food and Nutrition Research, 56, (pp. 104-140). Amsterdam: Elsevier/Academic Press.
Robinson, A. R., MacLean, K. S., MacConnell, H. M. (1989). Heavy metal, $\mathrm{pH}$, and total solid content of maple sap and syrup produced in eastern Canada. J. Assoc. Anal. Chem. 72 (4), 674-679.

Sehm, E. (2007). Birkensaft. Das Gesundheitselixier aus der Natur. Norderstedt: Books on Demand GmbH. $52 \mathrm{~S}$.

Tanner, H., Brunner, H. R. (1987). Getränke - Analytik. Schwäbisch Hall: Heller Chemie - Verwaltungsgesellschaft mbH, S. 93-94.

Theriault, M., Caillet, S., Kermasha, S., Lacroix, M. (2006). Antioxidant, antiradical and antimutagenic activities of phenolic compounds present in maple products. Food Chem., 98 (3), 490-501.

Wong, B. L., Bagget, K. L., Rye, A. H. (2003.). Seasonal patterns of reserve and soluble carbohydrates in mature sugar maple (Acer saccharum). Can. J. Bot., 81 (8), 780-788.

Received 31 August 2012

\section{BIOLOĢISKI AKTĪVO SAVIENOJUMU UN MINERĀLVIELU NOTEIKŠANA BĒRZU UN KLAVU SULĀS}

Bērzu un kḷavu sulas satur ogḷhidrātus un organiskās skābes, B grupas vitamīnus un C vitamīnu, flavonoīdus, glikozīdus un minerālvielas. Pētîjuma mērḳis - noteikt bioloǵiski aktīvo savienojumu un minerālvielu saturu Latvijas bērzu (Betula pendula Roth.) un kḷavu (Acer platanoides) sulās. Lai raksturotu minerālvielu kopējo daudzumu, tika mērīta elektrovadītspēja (bērzu un kḷavu sulās atbilstoši 629 un 967 $\mu \mathrm{S} / \mathrm{cm}$ ). Minerālvielu saturs tika noteikts spektrofotometriski. Bērzu un kḷavu sulās tika noteikti kopējais skābums (atbilstoši 0,50 un 0,70 mmol NaOH uz litru sulas) un formaldehīdskaitḷi (atbilstoši (0.25 and $0.20 \mathrm{mmol} \mathrm{NaOH}$ uz litru sulas). Kḷavu sula satur vairāk proteīnus nekā bērzu sula (atbilstoši 171 and $127 \mathrm{mg} / \mathrm{l}$ ). Fruktozes, glikozes un saharozes saturs tika noteikts, izmantojot augstefektīvu škiidrumu hromatogrāfiju. Askorbīnskābes saturs tika noteikts jodometriski. Kā standartvielu izmantojot kvercetīnu, tika raksturots antioksidantu saturs un bērzu sulā tas bija $0,35 \mu \mathrm{g}$ kvercetīna ekvivalentu $(\mathrm{QE}) / 1$, bet kḷavu sulā $0,77 \mu \mathrm{g}$ QE/l. Kopumā Latvijas kḷavu sula satur vairāk bioloğiski aktīvo savienojumu un minerālvielu nekā bērzu sula. 